Aleksandra Petronijević

Mediterranean University,

Faculty of Economics and Business Podgorica,

Radmila Janičić ${ }^{2}$

University of Belgrade

Faculty of Organizational Sciences
ORIGINAL SCIENTIFIC ARTICLE

DOI: 10.5937/ekonomika2103001P

Received: April, 14. 2021.

Accepted: Jun, 18. 2021.

\title{
FACTORS THAT INFLUENCE CULTURAL TOURISTS TO USE E-WOM BEFORE VISITING MONTENEGRO
}

\begin{abstract}
Aiming to expend the existing knowledge regarding behavioural patterns of cultural tourists who are visiting Montenegro, the purpose of this research is to identify the main reasons that motivate cultural tourists to use e-WOM as a source of information about this destination. To fulfil this task a structured questionnaire was designed and a field research was carried out during 2019 among 376 cultural tourists who used e-WOM to gain more information about Montenegro. Twentyseven indicators were identified and grouped in three groups of factors of influence which were examined using one-way analysis of variance and independent sample T-test. Besides the respondents' personal attitude, the research shows that certain demographic characteristics and the respondents' country of origin influenced their propensity in using e-WOM prior to visiting this destination. By identifying concrete reasons why cultural tourists use eWOM, this study offers insights that can be useful in designing future destination marketing strategies.
\end{abstract}

Key words: cultural tourists, e-WOM, main reasons, cultural tourism, destination, marketing

JEL classification: L82, M31, Z32

\section{ФАКТОРИ КОЈИ УТИЧУ НА ТУРИСТЕ КУЛТУРНОГ ТУРИЗМА ДА КОРИСТЕ ЕЛЕКТРОНСКУ ПРЕПОРУКУ ПРИЈЕ ПОСЈЕТЕ ЦРНЕ ГОРЕ}

\begin{abstract}
Абсстракт
Тежећи проширењу постојећег знања о обрасиима понашања туриста културног туризма који посјећују Црну Гору сврха истраживања је утврђивање главних разлога који мотивишу туристе културног туризма да користе електронску препоруку као извор информисања о овој дестинацији. Да би се испунио овај задатак током 2019. године дизајниран је структурирани упитник и спроведено теренско истраживање на узорку од 376 туриста културног туризма који су користили електронске препоруке како би дошли до више информащија
\end{abstract}

\footnotetext{
${ }^{1}$ aleka@t-com.me, ORCID ID. 0000-0003-2822-3284

${ }^{2}$ radmila.janicic@fon.bg.ac.rs, ORCID ID. 0000-0001-9466-9984
} 
о Црној Гори. Утврђено је двадесет и седам индикатора који су груписани у три групе фактора од утищаја и потом истражени путем једносмјерне анализе варијансе и T-теста независних узорака. Поред личног става испитаника резултати показују да су одређене демографске карактеристике као и земьа поријекла испитаника играли значајну улогу по питању њихове склоности ка коришћењу електронске препоруке прије саме посјете дестинације. Утврђивањем конкретних разлога ради којих туристи културног туризма користе електронску препоруку истраживање пружа сазнања која могу бити корисна током обликовања будућих маркетинишких стратегија дестинащије.

Кључне ријечи: туристи културног туризма, еWОМ, главни разлози, културни туризам, маркетинг, дестинација

\section{Introduction}

Internet and digital media, as modern sources of information, have an inevitable impact on our daily lives and behaviour. They constantly change the methods of obtaining information making it easier for us to make our decisions, which reflects itself on the travel industry as well. While forming the first impression of a destination, tourists increasingly rely on data obtained independently using devices that support an internet connection (European Travel Commission, 2019). While researching different characteristics and tourism offers of several destinations, one can notice a growing number of websites that provide ratings, tips, opinions, detailed descriptions and different posted experiences shared by experienced tourists or people who have already had the opportunity to visit and stay for a certain period of time in the given destinations. These tips, experiences, elaborated attitudes, visual contents like videos or images and similar pieces of information are integral parts of the electronic word of mouth promotion, whose essence to facilitate the process of making the right travel decision is very similar to the essence of the classic word of mouth promotion. Word of mouth marketing is one of the oldest ways of transmitting information (Dellarocas, 2003) and can be explained as interpersonal communication between customers about a product, service or company where the source of information is considered independent in terms of commercial impact (Litvin, Goldsmith \& Pan, 2008). Traditionally, direct sharing of personal experience with another person is considered to be one of the most significant factors influencing the future behaviour of a potential customer (Daugherty \& Hoffman, 2014). Due to the widespread of the internet and the digital transformation affecting peoples' lives, digital platforms caused the emergence of a new version of word-of-mouth marketing, the electronic word of mouth or eWOM, which enables instant sharing of information (social media, review websites, blogs, etc.) and exchange of advice and experiences just online instead of in person, being the main difference between interpersonal and electronic word of mouth promotion (Cheung \& Thadani, 2012). In essence, digital word of mouth marketing is a positive or negative statement about a product, company or media personality (in this case a cultural tourism destination) by a potential, current or former customer/user of the service (in this case a cultural tourist who has gained personal experience while staying in a given destination) which is widely available to all interested parties online (Thorson \& Rogers, 2006). Since all information is available online, it is easily disseminated and reaches a large number of potential tourists. Therefore, marketers 
and managers have to know everything about modern technologies and options they carry, especially when it comes to social networks that nowadays make a huge part of consumers' life and serve as information systems for the customers (Becic, Stojanovic \& Nikolic, 2018). Interactivity, fastness and a high level of availability of this way of transmitting information ensures easy exchange of travel experiences and reduces the subjectively perceived level of uncertainty and risk while choosing a destination that could meet the needs of a given person or group of people who have the desire and means to travel. Fast and wide spreading of electronic word of mouth or eWOM is supported by the role that is attributed to the Internet, as well as the frequency and level of use of technological inventions in terms of modern communication. The presence of technology in our lives is illustrated by the following data: $58 \%$ of the global population uses internet every day; more than one billion people on the planet use Facebook every day; over 100 million people use Instagram every month; and 330 million use Twitter to promote numerous interesting contents (www.statista.com). Trip Advisor has an average of 390 million visits, 435 million shared experiences about restaurants, accommodation units, attractions and services, and counts over 280 experiences, testimonials and impressions shared via this communication platform every minute (www.tripadvisor. com). This data illustrates the extent to which the internet and digital marketing have changed our habits, and thus our lifestyle, as well as how willing experienced tourists are to share their experiences with others. Therefore, we can conclude that Kotler's statement that the decisionmaking process is no longer a process that implies independence and isolation (Kotler, 2003) also describes the current market situation very well.

Given that eWOM has a considerable role in influencing and forming attitudes and behavioural intentions (Amalia, 2018), and yet it is insufficiently researched in cultural tourism, the purpose of this research is to identify the main reasons that influence cultural tourists to use e-WOM as a source of information about Montenegro. Understanding this basic question means understanding the initial driving force that attracts cultural tourists to choose this means of information, taking into account that they have an abundance of alternative ways of gaining information about a destination (e.g., catalogues, video contents, tour operator materials, etc.) at their disposal. This moment makes this basic question, that might seem simple at first glance, but whose concrete answer is not so easy to find, so essential in order to gain new insights and better understand how cultural tourists think and what makes them use eWOM prior to visiting Montenegro. Due to a modest amount of research on this concrete topic, about this concrete tourism segment and from this desired perspective a smallscale pilot field research and in-depth interviews were needed and therefore conducted during the same year, in 2019, prior to designing a structured questionnaire which made it possible to identify 27 indicators or potential reasons why cultural tourists used eWOM as a source of informing about Montenegro, which were later included in the main research. The aim of the study is to identify the main factors that influence cultural tourists to use eWOM prior to visiting Montenegro, resulting in better understanding of behavioural patterns of cultural tourists linked to the phase of gathering information about this destination. In line with the purpose and aim of this paper, the following hypotheses were constructed:

H0: eWOM makes it easier for cultural tourists to choose a destination;

$\mathrm{H} 1:$ eWOM inspires cultural tourists which attractions and activities to include;

H2: The less well-known a destination the more cultural tourists turn to eWOM;

H3: eWOM lowers the level of uncertainty as to what to expect from a destination. 


\section{Literature review}

Advances in technology, internet and social media are changing the way information and tourism experiences are transmitted (Munar \& Jacobsen, 2014). Technological advancements have upgraded the concept of the recommendation itself and translated it into a digital form that is able to reach a wide audience in a short period of time (Abubakar \& Ilkan, 2013). The digital world allowing customers easy access to all possible information and their sharing with a large number of people gave the term recommendation a new dimension and caused the emergence of a new term which was digital/electronic word of mouth recommendation that was much more accessible and widespread, compared to the classic word of mouth recommendation (Akyuz, 2013). In addition, the digital world made an individual more accessible since by creating digital content it became possible to interact with individuals without interrupting their usual media interaction (Vidakovic, Vidakovic, 2017). Nowadays, social media and digital communication platforms for sharing knowledge, expressing emotions and conveying experiences are used much more frequently and reach many more people than ever before (Jacobsen \& Munar, 2012), which is evident in tourism as well since it is one of the most popular ways for tourists to get the necessary information about tourist destinations (Ladhari \& Michaud, 2015). eWOM provides abundant information support assisting tourists' in making their decisions (Jacobsen \& Munar, 2012), affecting tourists' travel intentions (Doosti et al., 2016), destination selection (Jalilvand \& Samiei, 2012) and destination impression (Abubakar, 2016) emphasising even more the importance of timely monitoring of tourism trends. Understanding behavioural patterns is a complex task, yet a crucial one, since understanding the behaviour of tourists helps actors in the tourism sector shape their products and services, enhance their strategies, and ensures the satisfaction of their customers (Senic, Milojevic, 2017). Due to its widespread and impact on a global level, the power of digital referral keeps on being an interesting inspiration to research from several different aspects: credibility, effect, level of interpersonal impact, etc. (Park et al., 2011). Some of the most common perspectives are linked to analysing the impact of eWOM on tourists' attitudes and intentions to visit a destination (Ladhari \& Michaud, 2015; Amalia et al., 2018), tourists' motives for engaging in eWOM (Bronner \& Hoog, 2011; Akyuz, 2013; Khan \& Khan, 2016), the impact of eWOM on tourists' destination choice (Jacobsen \& Munar, 2012; Jalivand \& Samiei, 2012), motivations for sharing tourism experiences via eWOM (Munar \& Jacobsen, 2014) and factors influencing eWOM effects (Park, Yao \& Kang, 2011). If we take into account all of the above, we can better understand why the electronic word of mouth, or eWOM, keeps on inspiring many marketers and researches to keep on exploring it from several different perspectives. Research shows that electronic or digital recommendation is constantly growing in popularity since it can offer significant pieces of information and needed support to tourists while they are making decisions, as well as influence destination promotion (Jacobsen \& Munar, 2012). Khan and Khan (2016) pointed out that "tourists seek eWOM for convenience and ease of accessing information" (p.33) linked to experiences of others who had already had the chance to visit a certain destination. It can increase the desire to travel, influence the choice of the destination itself and the impression that will be spread about it (Jalilvand \& Samiei, 2012) placing the analysing of digital content at the heart of digital marketing, making it a trend which doesn't seem to be revising any time soon since it keeps on influencing consumer purchasing decisions (Efomi, 2019). The importance of this type of marketing is supported by the fact that people influence others in the role of a free 
marketer who is much more convincing than any advertisement or seller (Kotler, 2003). Its accessibility encourages travellers to rely on the opinion of others influencing many travelrelated decisions to be made online, since travellers are relying heavily on social networks to gain relevant, complete and timely information (Khan \& Khan, 2016), supported also by the presence of keenness to be able to compare evaluations of others and form their own judgement (Bronner \& Hoog, 2011; Kim, Mattila \& Baloglu, 2011). Although tourism motivation has been widely investigated by scholars, yet there are only a few studies on tourists' eWOM motivations (Wu \& Pearce, 2016; Noh, Lee \& Hwang, 2017; Zhou et al., 2019) making the topic of researching concrete reasons for using eWOM in tourism still a current topic, especially when it comes to analysing selective forms of tourism and behaviour of tourism segments of special interest tourism.

\section{Research Design and Methodology}

Quantitative research was conducted on a sample of 376 respondents. Data were collected in April-June and September-November 2019 in the territory of Montenegro. This study covered the coastal (75\% of valid questionnaires) and central region of the country ( $25 \%$ of valid questionnaires). Taking into account that the target group were cultural tourists, in order to provide an adequate sample of respondents, data were collected at highly attractive sites for cultural tourists (Table 1). The survey was conducted during the pre- and post-tourism season, since that is the period during the year when a significant concentration of visitors highly interested in cultural attractions visit Montenegro. The sample included foreign visitors who stated that one of the motives of their trip was linked to at least one element of the cultural tourism offer of Montenegro, who used the Internet while researching potential travel destinations, who used digital communication platforms that allowed sharing and exchanging destination experiences and who spent minimum two nights in Montenegro. The diversity of the analysed sample in terms of country of origin and mentality was taken into account to ensure the representativeness of the analysed sample of respondents and gain better insight into the behaviour patterns and reasons for using eWOM as a source of information by tourists coming from different parts of the world. In order to collect the necessary data, as well as to ensure the anonymity of the respondents, a structured questionnaire was designed. The interviewer kindly explained the research purpose and future use of gathered data to all potential respondents before they made their decision to participate in the study. 450 questionnaires were distributed, while the total number of valid questionnaires was 376. Accordingly, a response rate of $83.5 \%$ was achieved, which is considered very satisfactory for the needs of this research. Data were collected using a specially designed questionnaire compiled in English and German that consisted of concise close-ended questions, lists of statements and a few open-ended questions. Each statement in the questionnaire was accompanied by a five-point Likert scale which expressed the degree of agreement or disagreement with a particular statement (5 - highest value, 1 - lowest value), which was used as a base to calculate average scores for each individual statement, as well as the total score based on average rating, which allowed better insight into the attitudes and preferences of cultural tourists linked to eWOM. The collected data were analysed using IBM SPSS Statistics 23 . After creating a database, the data were statistically processed using descriptive statistics, Pearson correlation (r), exploratory factor analysis, independent sample 
T-test and one-way analysis of variance (ANOVA) as analysis tools in order to analyse various variables and relationships between them. Statistical methods provided a better insight into the profile of cultural tourists, most popular motives to use eWOM, impact of all three factor groups on the respondents' behaviour and insight into propensity in using eWOM in respect to the respondent's gender, age, educational level and region of origin.

\section{Research Results and Discussion}

In order to analyse the results and identify motivational factors that influence cultural tourists the most to turn to eWOM as a source of information prior to visiting Montenegro as their next holiday destination, besides taking into account the results of descriptive statistics, exploratory factor analysis, independent sample T-test and one-way analysis of variance (ANOVA) were used as analysis tools. The results are presented below.

Table 1: List of sites where data were collected April-June \& September-November 2019 ( $n=376)$

\begin{tabular}{|c|c|c|c|c|}
\hline Region & Location & Type of attraction & $\begin{array}{c}\text { Number of } \\
\text { respondents }\end{array}$ & $\%$ \\
\hline Coastal region & Herceg Novi & Old town & 46 & 12.2 \\
\hline & Perast & Old town & 67 & 17.8 \\
\hline & Kotor & Old town & 82 & 21.8 \\
\hline & Budva & Old town & 53 & 14.0 \\
\hline & Bar & Old town & 34 & 9.0 \\
\hline Central region & Cetinje & Old historic urban centre & 52 & 13.8 \\
\hline & Njegusi & Old historic village & 28 & 7.4 \\
\hline & Virpazar & Traditional fishermen village & 14 & 3.7 \\
\hline & \multicolumn{2}{|c|}{ Total: } & 376 & 100 \\
\hline & Total - Coastal region: & 942 & 75 \\
\hline
\end{tabular}

Source: Authors'research

Table 2: Demographic profile of the respondents $(n=376)$

\begin{tabular}{|c|c|c|c|c|}
\hline Variables & Description & Frequency & Valid Percent (\%) & $\begin{array}{c}\text { Cumulative Percent } \\
\text { (\%) }\end{array}$ \\
\hline \multirow{3}{*}{ Gender } & Male & 169 & 44.9 & 44.9 \\
\cline { 2 - 5 } & Female & 207 & 55.1 & 100.0 \\
\hline \multirow{3}{*}{ Age } & $25-38$ & 107 & 28.5 & 28.5 \\
\cline { 2 - 5 } & $39-51$ & 142 & 37.8 & 66.2 \\
\cline { 2 - 5 } & $52+$ & 127 & 33.8 & 100.0 \\
\hline \multirow{3}{*}{ Educational Level } & High School & 3 & 0.8 & 0.8 \\
\cline { 2 - 5 } & College & 44 & 11.7 & 12.5 \\
\cline { 2 - 5 } & University & 257 & 68.4 & 80.9 \\
\cline { 2 - 5 } & Masters & 62 & 16.5 & 97.3 \\
\cline { 2 - 5 } & PhD & 10 & 2.7 & 100.0 \\
\hline
\end{tabular}




\begin{tabular}{|c|c|c|c|c|}
\hline \multirow{4}{*}{$\begin{array}{c}\text { Monthly Net } \\
\text { Income }(€)\end{array}$} & $<1,500$ & 75 & 20.2 & 20.2 \\
\cline { 2 - 5 } & $1,500-2,500$ & 142 & 37.5 & 57.7 \\
\cline { 2 - 5 } & $2,501-3,500$ & 124 & 33.0 & 90.7 \\
\cline { 2 - 5 } & $>3,501$ & 35 & 9.3 & 100.0 \\
\hline \multirow{5}{*}{ Region of Origin } & Central Europe & 100 & 26.6 & 26.6 \\
\cline { 2 - 5 } & Northern Europe & 118 & 31.4 & 32.5 \\
\cline { 2 - 5 } & Western Europe & 44 & 11.7 & 44.1 \\
\cline { 2 - 5 } & Eastern Europe & 3 & 0.8 & 53.7 \\
\cline { 2 - 5 } & Southern Europe & 9 & 2.4 & 85.1 \\
\cline { 2 - 5 } & North America & 44 & 11.7 & 96.8 \\
\cline { 2 - 5 } & Asia & 40 & 10.6 & 97.6 \\
\cline { 2 - 5 } & Other & 18 & 4.8 & 100.0 \\
\hline
\end{tabular}

Source: Authors'research

Table 2 shows the output of descriptive statistics linked to the demographic profile of the analysed sample of cultural tourists who spent minimum two nights in Montenegro and used eWOM as a source of information before they made their final decision to visit that destination. Descriptive statistics shows that out of 376 respondents who participated in this study, there were $10.2 \%$ more female than male respondents. Most respondents were 39-51 years old (37.8\%), had a university degree $(60.4 \%)$ and a monthly net income of $€ 1,500$ $2,500(37.5 \%)$. The highest percentage of the respondents $(72.9 \%)$ came from Europe. Further analysis using descriptive statistics showed that most participants originated from Northern European countries (31.4\%) and Central European countries (26.6\%). In addition, the highest percentage $(85.1 \%)$ of visitors came for the first time and on average they had compared 3 destinations using eWOM before they made their finial choice.

Table 3: Top 10 reasons for using eWOM as a source of information about Montenegro

\begin{tabular}{|c|c|c|c|}
\hline Indicator & Mean & SD & Rank \\
\hline $\begin{array}{l}\text { Travel reviews, recommendations and posted experiences gave me ideas } \\
\text { which cultural attractions, activities or experiences to include during my } \\
\text { stay }\end{array}$ & 4.18 & 0.81 & 1 \\
\hline $\begin{array}{c}\text { Reviews and shared experiences with visual contents like pictures or } \\
\text { videos, helped me make my travel decision }\end{array}$ & 4.14 & 0.93 & 2 \\
\hline $\begin{array}{l}\text { Since nobody in my family/circle of friends had had the chance to visit } \\
\text { that destination, I relied on online reviews, recommendations and shared } \\
\text { experiences posted by people who gained first-hand experience }\end{array}$ & 4.09 & 0.85 & 3 \\
\hline $\begin{array}{l}\text { The more positive the posted reviews and shared experiences are the more } \\
\text { confident I feel to give a cultural experience a chance }\end{array}$ & 4.02 & 0.89 & 4 \\
\hline $\begin{array}{l}\text { Consulting posted or shared experiences online of a person who had } \\
\text { already had the chance to gain first-hand experience in Montenegro made } \\
\text { me feel more confident in making my travel decision }\end{array}$ & 4.00 & 0.91 & 5 \\
\hline $\begin{array}{l}\text { Posted travel reviews, recommendations and experiences help me avoid } \\
\text { mistakes }\end{array}$ & 3.97 & 0.84 & 6 \\
\hline $\begin{array}{l}\text { The less I know about a destination the more I trust travel reviews, } \\
\text { recommendations and posted experiences }\end{array}$ & 3.88 & 0.94 & 7 \\
\hline $\begin{array}{l}\text { Travel reviews, recommendations and posted experiences about cultural } \\
\text { sites and attractions in Montenegro motivated me to visit the same places }\end{array}$ & 3.85 & 0.93 & 8 \\
\hline
\end{tabular}




\begin{tabular}{|c|c|c|c|}
\hline $\begin{array}{c}\text { Most recent reviews and shared experiences about Montenegro, not older } \\
\text { than } 4 \text { months, helped me make my travel decision }\end{array}$ & 3.84 & 0.87 & 9 \\
\hline $\begin{array}{c}\text { Detailed reviews and shared experiences offering useful tips about } \\
\text { means of transport, accommodation, cultural attractions and other } \\
\text { relevant experiences made it easier for me to make my decision and visit } \\
\text { Montenegro }\end{array}$ & 3.81 & 0.84 & 10 \\
\hline
\end{tabular}

Source: Authors'research

Table 3 shows the list of the most influential factors ranked by their level of strength (5 - strongest level of impact; 1 - no impact) that influenced cultural tourists to use eWOM as a source of information regarding Montenegro as a potential travel destination. The strongest factor, the first one in Table 3, illustrates the importance of the practical and useful side of eWOM offering ideas and inspiring people which attractions to visit, as well as which activities and experiences to include during their stay in Montenegro. The second strongest factor emphasises the high level of attractiveness, importance and usefulness of the presence of visual contents in online travel reviews, which influenced the outcome of the travel decision among a significant number of respondents. The third strongest factor shows that respondents are likely to consult and rely on eWOM as a practical option for accessing information if nobody in their family/ circle of friends had ever had the chance to visit a given destination before. Generally, the results illustrated in Table 3 indicate that the respondents see eWOM as a source of information that helps them choose a destination and makes them feel more confident in the choice they have made, it helps them reduce uncertainty and the feeling of taking a risk of making mistakes especially while deciding about a destination that the respondents know very little about. The third strongest motive emphasises the significance of one of the main benefits of eWOM linked to getting access to first-hand experiences from people who had the chance to visit Montenegro, especially if nobody belonging to the respondents' family or circle of friends has had the chance to visit this destination before.

Table 4: Factors whose level of popularity is below 3.00

\begin{tabular}{|c|c|c|c|}
\hline Factor & Mean & SD & Rank \\
\hline $\begin{array}{c}\text { Consulting travel reviews, recommendations and experiences is almost } \\
\text { like receiving advice from a friend }\end{array}$ & 2.97 & 1.48 & 1 \\
\hline $\begin{array}{l}\text { Travel reviews, recommendations and posted experiences have a } \\
\text { bigger influence on me, compared to advice of tourism workers }\end{array}$ & 2.92 & 1.32 & 2 \\
\hline $\begin{array}{l}\text { In choosing my next destination travel reviews and shared experiences } \\
\text { with high ratings strongly influenced my travel decision }\end{array}$ & 2.82 & 1.38 & 3 \\
\hline $\begin{array}{l}\text { I focused on all online reviews and shared experiences and the overall } \\
\text { opinion about Montenegro strongly influenced my travel decision }\end{array}$ & 2.88 & 1.53 & 4 \\
\hline
\end{tabular}

Source: Authors'research

Table 4 shows factors whose level of influence on the respondents' choice to use eWOM as a source of information about Montenegro is below 3.00 (5 - strongest level of impact; 1 - no impact). It is interesting to notice the variations in the respondents' opinions on whether there is a similarity between consulting travel reviews and receiving advice from a friend. Further analysis showed that $76 \%$ of the respondents saw eWOM as a really good alternative, almost like getting advice from a friend in case they could not ask anybody belonging to their family or circle of friends about their impression of Montenegro. In addition, the relationship between the attitude that consulting travel 
reviews is almost like receiving advice from a friend and the respondents' age has been analysed using the Pearson correlation (r). Preliminary analyses were performed to confirm the assumptions about normality, linearity and homogeneity of the variance. A strong negative correlation between both variables was calculated, $r=-0.55, n=376$, $\mathrm{p}<0.005$, indicating that the younger the respondents were the more likely it was for them to observe similarly eWOM and advice from a friend. Also, after completing the preliminary analyses, the relationship between the level of influence of posted travel experiences vs advice from a tourism worker and the age of the respondents was analysed using the Pearson correlation (r). A moderate negative correlation between both variables was calculated, $\mathrm{r}=-0.36, \mathrm{n}=376, \mathrm{p}<0.005$, whereby the respondents belonging to younger age groups were more likely to trust eWOM.

To identify the level of influence of motivational factors on the decision of cultural tourists to use eWOM as a source of information prior to making the decision to visit Montenegro, a principal component factor analysis with a verimax rotation was used. The Kaiser-Mayer-Olkin (KMO) measure of sampling adequacy is 0.91 (Table 5), confirming that the data and sample size are suitable since the mentioned value is higher than 0.6. Bartlett's Test of Sphericity is significant, $p<0.005$, confirming that there is a significant relationship between variables. All factors with an eigenvalue higher than 1 were preferred, as well as factors with factor loadings higher than 0.5. All 27 indicators had a factor loading higher than 0.5 , therefore no item was deleted. Table 5 shows the results of all 27 factors that influenced cultural tourists to use eWOM before making the decision to visit Montenegro during 2019. All indicators were divided into three groups of factors of influence: "need for guidance from experienced cultural tourists", "personal attitude towards eWOM", "characteristics and content of eWOM". The results indicate that "personal attitude towards eWOM" with 8.11 eigenvalue and $81.06 \%$ variance is the most essential factor group and main reason for cultural tourists to use eWOM before they made their final decision to visit Montenegro. The second influential factor group is "need for guidance from experienced cultural tourists" followed by "characteristics and content of eWOM".

Table 5: KMO and Bartlett's Test Results

\begin{tabular}{|c|c|c|}
\hline \multirow{2}{*}{ Kaiser-Meyer-Olkin Measure of Sampling Adequacy } & 0.913 \\
\hline \multirow{3}{*}{ Bartlett's Test of } \\
\cline { 2 - 3 } Sphericity & Approx. Chi-Square & 12027.871 \\
\cline { 2 - 3 } & $\mathrm{df}$ & 351 \\
\hline
\end{tabular}

Source: Authors' research

Table 6: Factor analysis of motives for using eWOM prior to visiting Montenegro

\begin{tabular}{|c|c|c|c|c|}
\hline Motivational factor groups with indicators & $\begin{array}{c}\text { Factor } \\
\text { loading }\end{array}$ & $\begin{array}{c}\text { Eigen } \\
\text { value }\end{array}$ & Variance & Reliability \\
\hline $\begin{array}{c}\text { F1 Need for guidance from experienced cultural } \\
\text { tourists }\end{array}$ & 6.93 & 69.27 & .94 \\
\hline
\end{tabular}




\begin{tabular}{|c|c|c|c|c|}
\hline Motivational factor groups with indicators & $\begin{array}{l}\text { Factor } \\
\text { loading }\end{array}$ & $\begin{array}{l}\text { Eigen } \\
\text { value }\end{array}$ & Variance & Reliability \\
\hline $\begin{array}{l}\text { eWOM made it easy for me to choose which } \\
\text { cultural day trips I needed to book }\end{array}$ & 0.90 & & & \\
\hline $\begin{array}{l}\text { Since nobody in my family/ circle of friends had } \\
\text { had the chance to visit that destination, I relied } \\
\text { on online reviews, recommendations and shared } \\
\text { experiences posted by people who gained first- } \\
\text { hand experience }\end{array}$ & 0.89 & & & \\
\hline $\begin{array}{l}\text { Travel reviews, recommendations and shared } \\
\text { experiences about cultural sites in Montenegro } \\
\text { motivated me to visit the same places }\end{array}$ & 0.86 & & & \\
\hline $\begin{array}{l}\text { Online presence and reputation of Montenegro } \\
\text { helped me shape my opinion about that } \\
\text { destination }\end{array}$ & 0.86 & & & \\
\hline $\begin{array}{l}\text { Consulting online shared experiences of persons } \\
\text { who had already had the chance to gain first-hand } \\
\text { experience in Montenegro made me feel more } \\
\text { confident in making my travel decision }\end{array}$ & 0.85 & & & \\
\hline $\begin{array}{l}\text { Reading experiences from people who had already } \\
\text { visited Montenegro made it easy to choose the } \\
\text { right cultural experiences }\end{array}$ & 0.83 & & & \\
\hline $\begin{array}{l}\text { Travel reviews, recommendations and shared } \\
\text { experiences encouraged me to visit Montenegro }\end{array}$ & 0.82 & & & \\
\hline $\begin{array}{l}\text { Travel reviews, recommendations and shared } \\
\text { experiences had a bigger influence on me, } \\
\text { compared to any advice from tourism workers }\end{array}$ & 0.80 & & & \\
\hline $\begin{array}{l}\text { Travel reviews and experiences gave me } \\
\text { ideas which cultural attractions, activities or } \\
\text { experiences to include during my stay }\end{array}$ & 0.76 & & & \\
\hline $\begin{array}{l}\text { Travel reviews, recommendations and posted } \\
\text { experiences made it easy to choose the most } \\
\text { suitable means of transport, accommodation and } \\
\text { restaurants }\end{array}$ & 0.74 & & & \\
\hline F2 Personal attitude towards eWOM & & 8.11 & 81.06 & .97 \\
\hline $\begin{array}{l}\text { Consulting travel reviews, recommendations and } \\
\text { experiences is almost like getting advice from a } \\
\text { friend }\end{array}$ & 0.96 & & & \\
\hline $\begin{array}{l}\text { I find travel reviews, recommendations and shared } \\
\text { experiences trustworthy }\end{array}$ & 0.94 & & & \\
\hline $\begin{array}{l}\text { The less I know about a destination the more I } \\
\text { trust travel reviews, recommendations and shared } \\
\text { experiences }\end{array}$ & 0.93 & & & \\
\hline $\begin{array}{l}\text { The more positive the posted reviews and shared } \\
\text { experiences are the more certain I feel that I need } \\
\text { to give a cultural experience a chance }\end{array}$ & 0.92 & & & \\
\hline $\begin{array}{l}\text { I find reading travel reviews, recommendations } \\
\text { and experiences fun and very useful in making } \\
\text { decisions }\end{array}$ & 0.91 & & & \\
\hline $\begin{array}{l}\text { The more positive the posted reviews and shared } \\
\text { experiences are the more confident I feel that I } \\
\text { need to book a certain cultural day trip or trips }\end{array}$ & 0.90 & & & \\
\hline $\begin{array}{l}\text { Travel reviews, recommendations and shared } \\
\text { experiences helped me make a good decision }\end{array}$ & 0.87 & & & \\
\hline
\end{tabular}




\begin{tabular}{|c|c|c|c|c|}
\hline Motivational factor groups with indicators & $\begin{array}{l}\text { Factor } \\
\text { loading }\end{array}$ & $\begin{array}{l}\text { Eigen } \\
\text { value }\end{array}$ & Variance & Reliability \\
\hline $\begin{array}{l}\text { Posted travel reviews, recommendations and } \\
\text { experiences helped me avoid mistakes }\end{array}$ & 0.87 & & & \\
\hline $\begin{array}{l}\text { Reading travel reviews, recommendations and } \\
\text { experiences is a habit of mine }\end{array}$ & 0.87 & & & \\
\hline $\begin{array}{l}\text { The more positive the posted reviews and shared } \\
\text { experiences are the more certain I feel that I need } \\
\text { to visit a cultural attraction }\end{array}$ & 0.85 & & & \\
\hline F3 Characteristics and content of eWOM & & 6.68 & 59.87 & .81 \\
\hline $\begin{array}{l}\text { Mostly I focused on positive reviews and shared } \\
\text { experiences and it strongly influenced my travel } \\
\text { decision }\end{array}$ & 0.89 & & & \\
\hline $\begin{array}{c}\text { Most recent reviews and shared experiences about } \\
\text { Montenegro, not older than } 4 \text { months, helped me } \\
\text { make my travel decision }\end{array}$ & 0.75 & & & \\
\hline $\begin{array}{l}\text { Detailed reviews and shared experiences } \\
\text { offering useful tips about means of transport, } \\
\text { accommodation, cultural attractions and other } \\
\text { relevant experiences made it easier for me to } \\
\text { decide to visit Montenegro }\end{array}$ & 0.73 & & & \\
\hline $\begin{array}{c}\text { Reviews and shared experiences with visual } \\
\text { contents like pictures or videos helped me make } \\
\text { my travel decision }\end{array}$ & 0.71 & & & \\
\hline $\begin{array}{l}\text { I focused on all online reviews and shared } \\
\text { experiences and the overall opinion about } \\
\text { Montenegro strongly influenced my travel } \\
\text { decision }\end{array}$ & 0.63 & & & \\
\hline $\begin{array}{l}\text { Mostly I focused on negative reviews and shared } \\
\text { experiences and it strongly influenced my travel } \\
\text { decision }\end{array}$ & 0.61 & & & \\
\hline $\begin{array}{c}\text { In choosing my travel destination, reviews and } \\
\text { shared experiences with high ratings helped } \\
\text { me the most and strongly influenced my travel } \\
\text { decision }\end{array}$ & 0.56 & & & \\
\hline
\end{tabular}

Source: Authors' research

Table 7: Differences in factor groups based on gender

\begin{tabular}{|c|c|c|c|c|}
\hline Factor group & Male & Female & T & Sig. \\
\hline Need for guidance from experienced tourists & 3.59 & 3.82 & -2.66 & 0.000 \\
\hline Personal attitude towards eWOM & 3.37 & 3.64 & -2.71 & 0.000 \\
\hline Characteristics and content of eWOM & 3.69 & 3.38 & -3.20 & 0.000 \\
\hline
\end{tabular}

Source: Authors'research

The T-test of independent samples compared the results of the levels of influence of all three factor groups in choosing eWOM with respect to the respondents' gender. "Need for guidance from experienced tourists" - male $(\mathrm{M}=3.59, \mathrm{SD}=0.72)$ and female respondents $(\mathrm{M}=3.81, \mathrm{SD}=0.89)$; $\mathrm{t}(376)=-2.66, \mathrm{P}<0.005$ (both ways) shows that the difference between the mean values of the characteristics by groups (average difference 
$=-0.22$ ) is very small (eta square $=0.018$ ). Also, analysis of the results of the second factor group "personal attitude towards eWOM" - male $(\mathrm{M}=3.37, \mathrm{SD}=0.89)$ and female respondents $(\mathrm{M}=3.64, \mathrm{SD}=1.04) ; \mathrm{t}(376)=-2.71, \mathrm{P}<0.005$ (both ways) shows that the difference between the mean values of the characteristics by groups (average difference $=-0.27$ ) is very small as well (eta square $=0.019$ ). Same goes for "Characteristics and contents of eWOM" - male $(\mathrm{M}=3.69, \mathrm{SD}=0.85)$ and female respondents $(\mathrm{M}=3.38$, $\mathrm{SD}=1.01) ; \mathrm{t}(376)=-3.20, \mathrm{P}<0.005$ (both ways) showing that the difference between the mean values of the characteristics by groups (average difference $=0.31$ ) is very small (eta square $=0.026$ ). The results indicate no great differences in the level of influence of all three factor groups in choosing eWOM as a source of information about Montenegro with respect to the gender.

Table 8: Differences in factor group level of influence based on age

\begin{tabular}{|c|c|c|c|c|c|}
\hline Factor group & Age & $\mathbf{M}$ & Eta Square & F & Sig. \\
\hline \multirow{3}{*}{ Need for guidance from experienced tourists } & $25-38$ & 4.17 & \multirow[b]{3}{*}{0.15} & \multirow[b]{3}{*}{35.049} & \multirow[b]{3}{*}{0.000} \\
\hline & $39-51$ & 3.71 & & & \\
\hline & $52+$ & 3.34 & & & \\
\hline \multirow[t]{3}{*}{ Personal attitude towards eWOM } & $25-38$ & 4.18 & \multirow[b]{3}{*}{0.27} & \multirow[b]{3}{*}{69.266} & \multirow[b]{3}{*}{0.000} \\
\hline & $39-51$ & 3.58 & & & \\
\hline & $52+$ & 2.89 & & & \\
\hline \multirow{3}{*}{ Characteristics and content of eWOM } & $25-38$ & 4.22 & \multirow[b]{3}{*}{0.29} & \multirow[b]{3}{*}{78.781} & \multirow[b]{3}{*}{0.000} \\
\hline & $39-51$ & 3.60 & & & \\
\hline & $52+$ & 2.87 & & & \\
\hline
\end{tabular}

Source: Authors'research

One-way factor analysis of variance investigated the level of influence of three factor groups ("need for guidance", "personal attitude" and "characteristics and content of eWOM") on the decision of cultural tourists belonging to different age categories to use eWOM as an information source prior to visiting Montenegro. The respondents were divided into three age groups: group 1 (25-38 years of age); group 2 (39-51 years of age); and group 3 (older than 52 years of age). A statistically significant difference was found $\mathrm{p}<0.005$ in the results between all three age groups regarding all three factor groups ("need for guidance from experienced tourists", "personal attitude towards eWOM" and "characteristics and content of eWOM"). The actual difference between the mean values of the respondents' answers in case of all three factor groups is significant, and the magnitude of this difference is expressed using the Eta square indicator. All three Eta square values show a high impact level. Subsequent comparisons using the Tukey HSD test in the first factor group, "need for guidance from experienced tourists", indicate that the mean value of group $1(\mathrm{M}=4.17, \mathrm{SD}=0.70)$ differs significantly from the mean value of group $3(\mathrm{M}=3.34, \mathrm{SD}=0.84)$. Similar results showed the analysis of the remaining two factor groups: "personal attitude towards eWOM" group $1(\mathrm{M}=4.18, \mathrm{SD}=0.70)$ and group $3(\mathrm{M}=2.89, \mathrm{SD}=0.84)$ and "characteristics and content of eWOM", group $1(\mathrm{M}=4.22, \mathrm{SD}=0.68)$ and group $3(\mathrm{M}=2.87, \mathrm{SD}=0.90)$. The given results lead to the conclusion that the younger the respondents, the more likely they are to choose eWOM 
as a source of information about Montenegro before they make their decision whether to visit the destination.

Table 9: Differences in factor groups levels of influence based on education

\begin{tabular}{|c|c|c|c|c|}
\hline Factor group & Level & $\mathbf{M}$ & F & Sig. \\
\hline \multirow{5}{*}{ Need for guidance from experienced tourists } & High School & 4.60 & \multirow{5}{*}{3.05} & \multirow{5}{*}{0.017} \\
\hline & College & 3.86 & & \\
\hline & University & 3.75 & & \\
\hline & Masters & 3.47 & & \\
\hline & $\mathrm{PhD}$ & 3.38 & & \\
\hline \multirow{5}{*}{ Personal attitude towards eWOM } & High School & 3.82 & \multirow{5}{*}{4.68} & \multirow{5}{*}{0.001} \\
\hline & College & 4.23 & & \\
\hline & University & 4.07 & & \\
\hline & Masters & 3.28 & & \\
\hline & $\mathrm{PhD}$ & 3.26 & & \\
\hline \multirow{5}{*}{ Characteristics and content of eWOM } & High School & 3.02 & \multirow{5}{*}{4.60} & \multirow{5}{*}{0.002} \\
\hline & College & 3.57 & & \\
\hline & University & 4.02 & & \\
\hline & Masters & 3.97 & & \\
\hline & $\mathrm{PhD}$ & 3.54 & & \\
\hline
\end{tabular}

Source: Authors'research

Table 9 shows the mean differences in levels of impact of all three factor groups/ reasons in influencing respondents to choose eWOM as a source of information prior to deciding to visit Montenegro with respect to their level of education. The first factor group "need for guidance form experienced tourists" doesn't show any significant variations in the level of its impact on the respondents' choice. The results show significant differences in the second and third factor group. "Personal attitude towards eWOM" ( $F=4.68$; $\mathrm{p}<0.005)$ influences the most respondents with a college $(\mathrm{M}=4.23)$ and university degree $(\mathrm{M}=4.07)$ to choose eWOM as the source of information about Montenegro. The difference between the mean values of all five categories of the respondents' education is moderate (Eta square=0.06), but it confirms the presence of different levels of impact of this factor group on the respondents' choice with respect to their level of education. "Characteristics and contents of eWOM" $(\mathrm{F}=4.60, \mathrm{p}<0.005)$ results indicate that this factors group has the strongest impact in choosing eWOM as an information source about Montenegro among the respondents with a university $(\mathrm{M}=4.02)$ and master degree $(\mathrm{M}=3.97)$. The difference between the mean values of all five categories of the respondents' educational level is moderate (Eta square $=0.06$ ), but it confirms the presence of different levels of impact of this factor group on the respondents' choice with respect to their level of education. The given results lead to the conclusion that personal positive attitude towards eWOM influenced the most respondents with a college degree to use eWOM as a source of information about a destination, while characteristics and contents of eWOM motivated the most respondents with a university degree to use eWOM as a source of information about Montenegro. 
Table 10: Differences in factor groups with respect to the region of origin

\begin{tabular}{|c|c|c|c|c|}
\hline Factor group & Region of origin & $\mathbf{M}$ & $\mathbf{F}$ & Sig. \\
\hline \multirow{8}{*}{ Need for guidance from experienced tourists } & North America & 4.16 & \multirow{8}{*}{3.64} & \multirow{8}{*}{0.001} \\
\hline & Asia & 4.08 & & \\
\hline & Central Europe & 3.71 & & \\
\hline & Northern Europe & 3.87 & & \\
\hline & Western Europe & 3.63 & & \\
\hline & Eastern Europe & 3.57 & & \\
\hline & Southern Europe & 3.46 & & \\
\hline & Other & 3.36 & & \\
\hline \multirow{8}{*}{ Personal attitude towards eWOM } & North America & 3.67 & \multirow{8}{*}{4.32} & \multirow{8}{*}{0.000} \\
\hline & Asia & 3.78 & & \\
\hline & Central Europe & 3.53 & & \\
\hline & Northern Europe & 3.29 & & \\
\hline & Western Europe & 4.17 & & \\
\hline & Eastern Europe & 3.76 & & \\
\hline & Southern Europe & 3.91 & & \\
\hline & Other & 3.28 & & \\
\hline \multirow{8}{*}{ Characteristics and content of eWOM } & North America & 4.11 & \multirow{8}{*}{4.16} & \multirow{8}{*}{0.000} \\
\hline & Asia & 3.71 & & \\
\hline & Central Europe & 4.00 & & \\
\hline & Northern Europe & 3.27 & & \\
\hline & Western Europe & 3.34 & & \\
\hline & Eastern Europe & 3.42 & & \\
\hline & Southern Europe & 3.52 & & \\
\hline & Other & 3.43 & & \\
\hline
\end{tabular}

Source: Authors' research

Table 10 shows the mean differences in the levels of influence of all three groups of factors/reasons for using eWOM as an information source about Montenegro with respect to the respondents' region of origin. All three factor groups show significant variations in terms of their levels of impact on respondents' reason of choice. "Need for guidance from experienced tourists" $(\mathrm{F}=3.64 ; \mathrm{p}<0.005)$ comes to the fore among the respondents coming from North American $(\mathrm{M}=4.16)$ and Asian $(\mathrm{M}=4.08)$ countries. In general, the difference between the mean values based on all eight regions of the respondents' origin is moderate (Eta square $=0.06$ ), but it confirms the presence of the most significant impact of this factor group on cultural tourists coming from North America and Asia compared to others. "Personal attitude towards eWOM" $(\mathrm{F}=4.32 ; \mathrm{p}<0.005)$ is emphasised among the respondents coming from Western Europe $(M=4.17)$ and Southern Europe $(M=3.91)$. The difference between the mean values of all eight regions of the respondents' origin is moderate (Eta square $=0.07$ ), but it confirms the presence of the most significant impact of this factor group on cultural tourists coming from Western Europe and Southern Europe, compared to other regions of origin. "Characteristics and content of eWOM" $(\mathrm{F}=4.16$; $\mathrm{p}<0.005)$ had the biggest impact on respondents' coming from North America $(\mathrm{M}=4.11)$ and Central Europe (4.00). The difference between the mean values of all eight regions of the respondents' origin is moderate (Eta square $=0.07$ ), but it confirms the presence of 
the most significant impact of this factor group on cultural tourists coming from North America and Central Europe.

Table 11: Hypothesis Test Results Summary

\begin{tabular}{|c|c|c|c|c|c|}
\hline Hypothesis & $\begin{array}{c}\text { Estimated Value }(\boldsymbol{\beta} \\
\text { value })\end{array}$ & $\begin{array}{c}\text { Standard } \\
\text { Error }\end{array}$ & Critical Ratio & P-value & Result \\
\hline H0 & 0.949 & 0.049 & 3.877 & 0.000 & Confirmed \\
\hline H1 & 0.802 & 0.041 & 4.008 & 0.000 & Confirmed \\
\hline H2 & 0.709 & 0.036 & 4.186 & 0.000 & Confirmed \\
\hline H3 & 0.851 & 0.044 & 3.994 & 0.000 & Confirmed \\
\hline
\end{tabular}

Source: Authors'research

Table 11 illustrates the results of hypothesises that have been tested by this research. Hypothesises are significant and can be accepted only if they meet the criteria of the value of the critical ratio $>1.968$ and $\mathrm{P}$-value of $<0.05$. Therefore, the results of hypothesis that were tested show all values of $t_{\text {value }}$ greater than $t_{\text {table }}=1,968(n=376)$. H0: direct effect of eWOM in easing the process of choosing a destination by cultural tourists $(0.949$ and $\mathrm{p}<0.000$ ) shows a positive and significant influence. $\mathrm{H} 1$ : direct effect of eWOM in inspiring cultural tourists to include cultural attractions and activities during their stay in Montenegro ( 0.802 and $\mathrm{p}<0.000)$ also shows a positive and significant influence. H2: the extent to which a destination is known on the tourism market $(0.709$ and $\mathrm{p}<0.000)$ proved to have a direct, positive, strong and significant effect on cultural tourists' decision to use eWOM as a source of information about Montenegro prior to their visit and H3: direct effect of eWOM in lowering the level of perceived uncertainty as to what cultural tourists can expect from Montenegro as a destination $(0.851$ and $\mathrm{p}<0.000)$ shows a positive and significant influence. Therefore, all four hypotheses in this study are accepted. These findings and insights offer contributions to cultural tourism, marketing communications and consumer behaviour literature.

\section{Conclusion}

To better understand the reasons why cultural tourists use eWOM prior to visiting Montenegro, the respondents were given a list of carefully chosen factors to assess the level of influence of each factor on their decision to use eWOM as a source of information about this destination. Several interesting findings emerged from this study. Besides the processed data confirming the significant positive relationship between convenience and ease of accessing information and motivation for using eWOM (Khan \& Khan, 2016; Abubakar, 2016; Doosti et al.), this research expended the list of motives for using eWOM and offered more concrete answers from the cultural tourist's point of view. It showed that the practical and useful side of eWOM linked to offering ideas and inspiring cultural tourists which attractions, sites and activities to include during their stay in Montenegro, especially among the respondents who could not ask anybody from their immediate social circle for a piece of advice, since nobody in their family or circle of friends had ever had the chance to visit Montenegro. Research has also shown that cultural tourists 
used eWOM since it made them feel more confident in making choices, it reduced the level of uncertainty in what to expect in the destination, especially among the respondents who know very little about Montenegro. Another very interesting motive driving cultural tourists to use eWOM as a source of information prior to visiting Montenegro is linked to getting access to first-hand experiences from people who had the chance to visit this destination. This insight is very interesting since it explains why the respondents used eWOM considering the abundance of other sources of information about this as well as other destinations. This indicates a strong role of horizontal communication between cultural tourists.

Another interesting observation emerged from analysing relationships between reasons/motives grouped in three groups of factors of influence and the demographic characteristics of the respondents. Results showed that the main cause for consulting eWOM was linked to the personal attitude of the respondents combined with the need for guidance or need for a piece of advice from an experienced cultural tourist. The results indicated no great differences in the level of influence of all factor groups in using eWOM as a source of information about Montenegro with respect to gender, but therefore significant differences were found with respect to age, level of education and country of origin. The research results confirmed all hypothesises showing a positive and significant influence of eWOM on easing the respondents' process of choosing a destination (H0), confirming a positive and significant effect of eWOM on inspiring cultural tourists to include cultural attractions and activities during their stay (H1), showing the presence of a direct, positive, strong and significant interdependence between the respondents' level of familiarity with a destination and willingness to turn to eWOM (H2), as well as proving the existence of a positive and significant influence of eWOM on lowering the level of uncertainty as to what the cultural tourists could expect form Montenegro during their vacation $(\mathrm{H} 3)$.

These findings expend current knowledge about the behavioural patterns of cultural tourists in terms of reasons for consulting eWOM while gathering information about a destination. Since the mentality, culture and system of values have a big impact on how people act, think, and get information, future studies could focus more on analysing differences in behaviour, needs and preferences of cultural tourists based on these socio-demographic characteristics. Since the analysed sample size $(n=376)$ is small, the findings should not to be generalised. The major factor that contributes to this is the fact that a high percentage of guests exploring the Montenegrin cultural offer are visitors who stay only a couple of hours in this destination since they are cruise ship guests or guests staying in neighbouring countries who cross borders and explore cultural attractions and sites only for a few hours without staying overnight. Because of the fact that the targeted sample were tourists (people staying in a destination, which is not the place of their permanent residence, longer than 24 hours), not cultural visitors or excursionist, the sample size could not be bigger. The primary method of collecting data was via printed questionnaire and future studies could explore behavioural patterns of cultural tourists by conducting digital surveys. 


\section{References}

Abubakar, A.M. (2016). Does eWOM influence destination trust and travel intention: A medical tourism perspective. Economic research, 29(1), 598-611.

Abubakar, A.M., Ilkan, M. (2013). More adverts or more Ewom. Journal of Business \& Financial Affairs, 2(2), 129. https://doi.org/10.4172/2167-0234.1000e129

Akyüz, A. (2013). Determinant Factors Influencing e-WOM. Mediterranean Journal of Social Sciences, 4(11), 159-166. https://doi.org/10.5901/mjss.2013.v4n11p159

Amalia, R., Yahya, A., Idris, S., Mahdi, S., Putra, T. (2018, October). Impact of Electronic Word of Moutn on Tourist Attitude and Intention to Visit Islamic Destinations. Paper presented at the 1st Aceh Global Conference (AGC 2018): Advances in Social Science, Education and Humanities Research of the Syiah Kuala University, Indonesia. https://doi.org/10.2991/agc-18.2019.105

Becic, S., Stojanovic, M., Nikolic, M. (2018). Role of marketing and social networks in improving business effectiveness. Ekonomika, 64(3). https://doi.org/10.5937/ ekonomika1803077b

Bronner, F., Hoog, R. (2011). Vacationers and eWOM: who posts and why, where and what. Journal of Travel Research, 50(1), 15-26. https://doi.org/10.1177/0047287509355324

Senic, R., Milojevic, S., (2017). Knowing tourists' behaviour: The imperative for a successful marketing strategy in tourism. Hotel and Tourism Management, 5(2), 61-73. UDC: $338.487: 659.127 .4$

Cheung, C., Thadani, D. (2012). The impact of electronic word-of-mouth communication: A literature analysis and integrative model. Decision Support Systems, 54(1), 461470. https://doi.org/10.1016/j.dss.2012.06.008

Daugherty, T., Hoffman, E. (2014). eWOM and the importance of capturing consumer attention within social media. Journal of Marketing Communication, 20(1-2), 82102. https://doi.org/10.1080/13527266.2013.797764

Dellarocas, C. (2003). The digitization of word of mouth: promise and challenges of online feedback mechanisms. Management Science, 49(10), 1407-1424.

Doosti, S., Jalivand, M.R., Asadi, A., Pool, J.K., Adl, P.M. (2016). Analysing the influence of electronic word of mouth on visit intention: The mediating role of tourist's attitude and city image. International Journal of Tourism Cities, 2(2), 137-148.

Efomi, C. (2019). Growth Marketing: Harnessing the combined power of branding and user-generated content. Glasgow, Efomi Ltd.

European Travel Commission, n.d, European Tourism Trends \& Prospects 2019, Quarterly Report (Q1/2019), viewed 18 June 2020, https://etc-corporate.org/reports/europeantourism-trends-prospects-q1-2019/

Jacobsen, J.K.S., Munar, A.M. (2012). Tourist information search and destination choice in a digital age. Tourism Management Perspectives, 1, 39-47. https://doi.org/10.1016/ j.tmp.2011.12.005

Jalilvand, M.R., Samiei, N. (2012). The impact of electronic word of mouth on a tourism destination choice: Testing the theory of planned behaviour (TPB). Internet Research 
Emerald Group Publishing Limited, 22(5), 591-612. https://doi.org/10.1108/ 10662241211271563

Khan, G., Khan, F. (2016). An investigation of motives to engage in eWOM among inbound Muslim tourists to Malaysia. Journal of Business and Globalisation, 16(1), 69-80. https: //doi.org/10.1504/ijbg.2016.073623

Kim, E.Y.K., Mattila, A.S., Baloglu, S. (2011). Effects of gender and expertise on consumers' motivations to read online hotel reviews. Cornell Hospitality Quarterly, 52(4), 339-406.

https://doi.org/10.1177/1938965510394357

Kotler, P., Kartajaya, H., Setiawan, I. (2017). Marketing 4.0, Moving from Traditional to Digital, USA: John Wiley \& Sons Inc.

Ladhari, R., Michaud, M. (2015). EWOM effects on hotel booking intentions, attitudes, trust, and website perceptions. International Journal of Hospitality Management, 46(3), 36-45. https://doi.org/10.1016/j.jhm.2015.01.010

Litvin, S.W., Goldsmith, R.E., Pan, B. (2008). Electronic word-of-mouth in Hospitality and Tourism Management. Tourism Management, 29(3), 458-468. https://doi.org /10.1016/j.tourman.2007.05.011

Munar, A.M., Jacobsen, J.K.S. (2014). Motivations for sharing tourism experiences through social media. Tourism Management, 43, 46-54, https://doi.org/10.1016/j. tourman. 2014.01.012

Noh, J.H., Lee, K.W., Hwang, J. (2017). The effect of motivational factor for using snss on tourist attitude. Tourism and Hospitality Management, 23(2), 185-194. https://doi. org/ 10.20867/thm.23.2.5

Park, C., Wang, Y., Yao, Y., Kang, Y.R. (2011). Factors influencing eWOM effects: Using experience, credibility and susceptibility. International Journal of Social Science and Humanity, 1(1), 74-79. https://doi.org/10.7763/ijssh.2011.v1.13

Redžić, D. (2019). Verski turizam kao faktor razvoja turizma u Grčkoj - studija slučaja o manastiru svetog Nektarija na Egini. Menadžment u hotelijerstvu $i$ turizmu, 7(1), 105-114.

Thorson, K.S., Rodgers, S. (2006). Relationships between blogs as eWOM and interactivity, perceived interactivity, and para-social interaction. Journal of Interactive Advertising, 6(2), 5-44. https://doi.org/10.1080/15252019.2006.10722117

Vidakovic, M., Vidakovic, D., (2019). Digital media, creativity and marketing, within the scope of the contemporary instant Culture. Annals of the Faculty of Economy in Subotica, 55(41), 131-144. https://doi.org/10.5937/aneksub1941131v

Wu, M.Y., Pearce, P.L. (2016). Tourism blogging motivations: Why do Chinese tourists create little "Lonely Planets"? Journal of Travel Research, 55(4), 537-549. https:// doi.org/10.1177/0047287514553057

Zhou, S., Yan, Q., Yan, M., Shen, C. (2019). Tourists' emotional changes and eWOM behaviour on social media and integrated tourism websites. International Journal of Tourism Research, 22(3), 336-350. https://doi.org/10.1002/jtr.2339

www.statista.com viewed 16 June 2020

www.tripadvisor.com viewed 14 June 2020 